For 28th Annual Electron Spectroscopy Society of America Meeting, Houston, Texas, October 5-9, 1970
UCRL-19628

Preprint

Conf-701003-4

\title{
HIGH VOLTAGE ELECTRON MICROSCOPY AT BERKELEY
}

\author{
G. Thomas
}

May 1970

AEC Contract No. W -7405 -eng -48

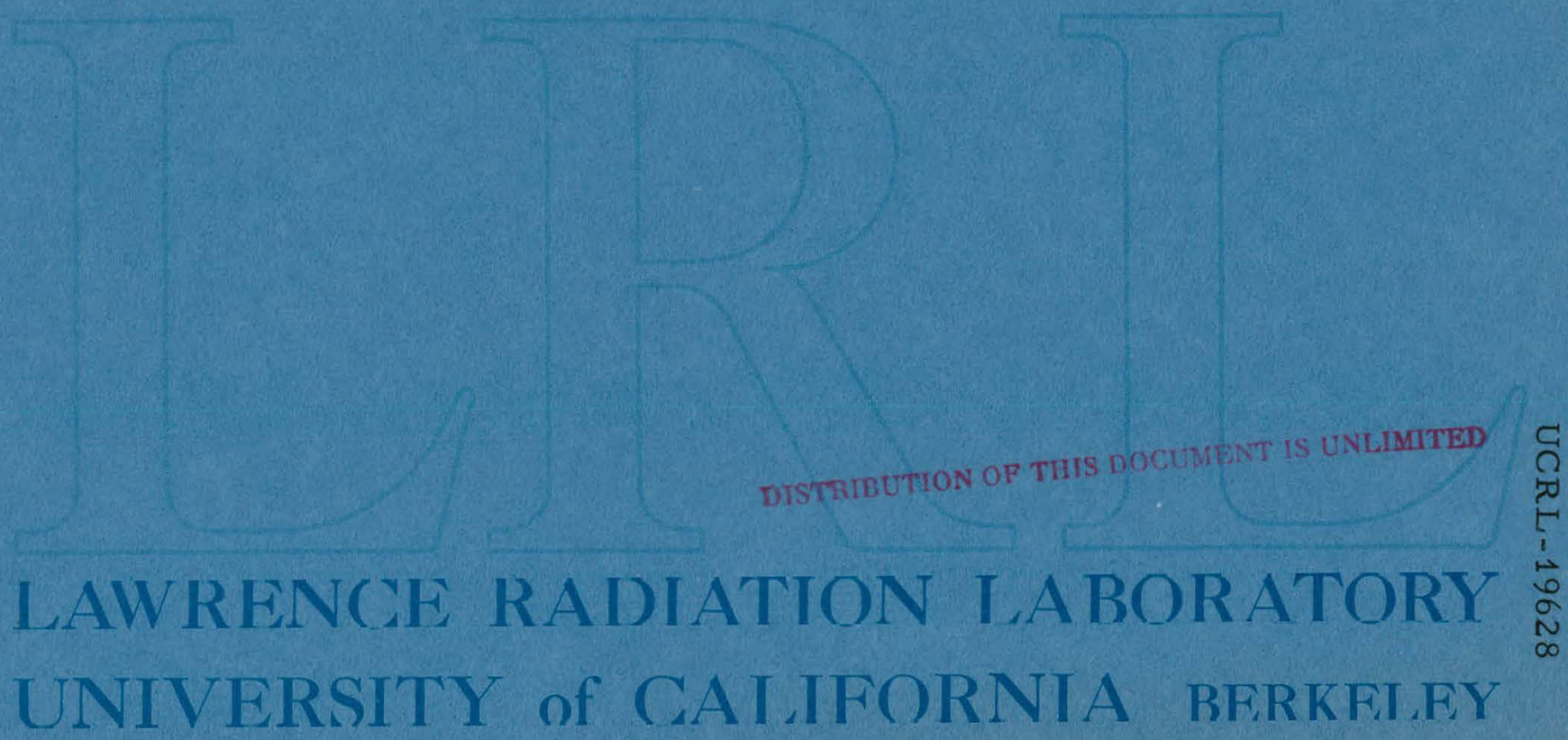




\section{DISCLAIMER}

This report was prepared as an account of work sponsored by an agency of the United States Government. Neither the United States Government nor any agency Thereof, nor any of their employees, makes any warranty, express or implied, or assumes any legal liability or responsibility for the accuracy, completeness, or usefulness of any information, apparatus, product, or process disclosed, or represents that its use would not infringe privately owned rights. Reference herein to any specific commercial product, process, or service by trade name, trademark, manufacturer, or otherwise does not necessarily constitute or imply its endorsement, recommendation, or favoring by the United States Government or any agency thereof. The views and opinions of authors expressed herein do not necessarily state or reflect those of the United States Government or any agency thereof. 


\section{DISCLAIMER}

Portions of this document may be illegible in electronic image products. Images are produced from the best available original document. 


\section{G. Thomas}

Inorganic Materials Research Division, Lawrence Radiation Laboratory and Department of Materials Science and Englneering, University of California, Berkeley, California 94720

A Hitach $1650 \mathrm{kV}$ electron microscope was installed at Berkeley in May 1969. (fig. 1) The fourier resolution test showed $4 \mathrm{~A}^{\circ}$ (fig. 2). The research program is centered around three principal advantages which open up new areas of microscopic analyses. These advantages are: a) the gain in transmission power with increasing voltage enabling thick specimens to be examined (up to about $6 \mu$ at $650 \mathrm{kV}$ depending on material) b) increased stability of roganic solids to radiation damage c) the disappearance voltage effect and fundamental advantages arising from many beam contrast phenomena at high energies.

The increase in transmission enables materials to be examined for which preparation of thin foils is difficult. It also enables specimens to be examined in some cases without any preparation. In the study of fossils it is particularly important to minimize preparation methods since material which has been imbedded in rocks for millions of years are usually brittle and difficult to section. Fig. 3 shows an example of the fibious structure of part of a graptolite specimen(1), which is $4 \times 10^{8}$ years old. Another example is a study of damage in as-received lunar surface particles (2) (fig. 4).

In ceramics research, we are studying the substructure and magnetic behavior of cobalt ferrites (3). Several interesting results have been obtained e.g. (1) the dislocations are not dissociated, but have a large Burgers vector $-6 A^{\circ}$ as deduced from comparing experimental and calculated dislocation image profiles(4), (2) Non-characteristic defects are produced as a result of radiation damage in the microscope, e.g. fig. 5. The defects are vacancy type and occur near the top surface of the foll. (3) Ferrimagnetic domains are resolved ( $f i g .6)$. The thickness fringes show that this material gives good resoltuion at thicknesses up.tn 11 .

Radiation damage is also being investigated in blological materials (5). Pre1iminary results indicate that the primary cause of damage is due to bond rupture and that specimen heating is not a primary cause except at relatively high electron intensities. Other biological studies include chromosomes and phages. Cooperative studies with the State Department of Public Health have involved studying air pollution samples on organic membranes which are too thick for $100 \mathrm{kV}$. Asbestos fibres $1 \mu$ thick of tremolite were identified by electron diffraction ( $f$ ig. $7 \mathrm{a}, \mathrm{b}$ ). These phases consist of many small polycrystals. Dr. W. L. Bell is working on many beam contrast effects with particular applications of the disappearance voltage phenomenon (6). Computer programs have been developed for a wide variet of cases. Other research activities include superconducting thin films, direct studies of phase transitions. in alloys, defects in semiconductors, slip band growth in copper, radiation damage and other metallurgical programs.

I wish to thank the U.S. Atomic Energy Commission and IMRD for continued financlal support and for making this research possible.

1. W. L. Bell and G. Thomas, Submitted to Science.

2. W. B. Berry, Takaji, G. Thomas and D. J. Jurica, These Proceedings.

3. L. De Jonghe, $\mathrm{Ph}$. D. thesis in progress.

4. L. De Jonghe and W. L. Bel1, Electron Microscopy 1970, Grenoble, Franre.

5. R. M. Glaeser, T. F. Budinger, B. M. Aebersold and G. Thomas, Ibid.

6. W. L. Bell, Ibld., also HVEM conferences Pittsburgh 1969, Harwell 1970. 
Fig. 1 The $650 \mathrm{kV}$ electron microscope at Berkeley.

Fig. 2 Showing lattice planes of $6 \mathrm{~A}^{\circ}$ and $4 \mathrm{~A}^{\circ}$ spacing in $\mathrm{K}_{2} \mathrm{PtCl}_{4}$.

Fig. 3 Fibres in orthograptus fossil.

Fig. 4 Radiation damage in Apollo 11 Lunar surface particles (unthinned).

Fig. 5 Radiation induced defects around conical etch pit (cobalt ferrite).

Fig. 6. Ferrimagnetic domains in cobalt ferrite.

Fig. 7 (a) Dark field image of tremolite asbestos in air pollution sample. (b) Diffraction pattern from (a).

This report was prepared as an account of work sponsored by the United States Government. Neither the United States nor the United States Atomic Energy Commission, nor any of their employees, nor any of their contractors, subcontractors, or their employees, makes any warranty, express or implied, or assumes any legal liability or responsibility for the accuracy, completeness or usefulness of any information, apparatus, product or process disclosed, or represents that its use would not infringe privately owned rights. 


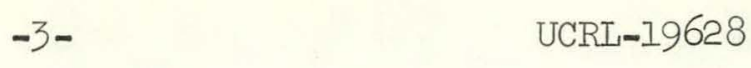

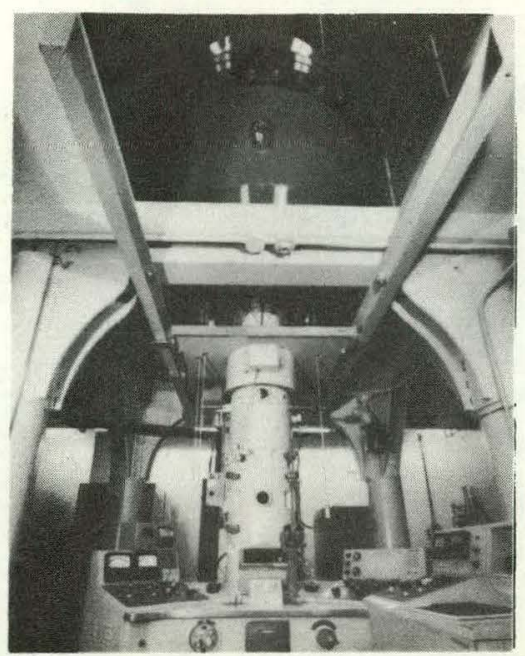

Fig. 1

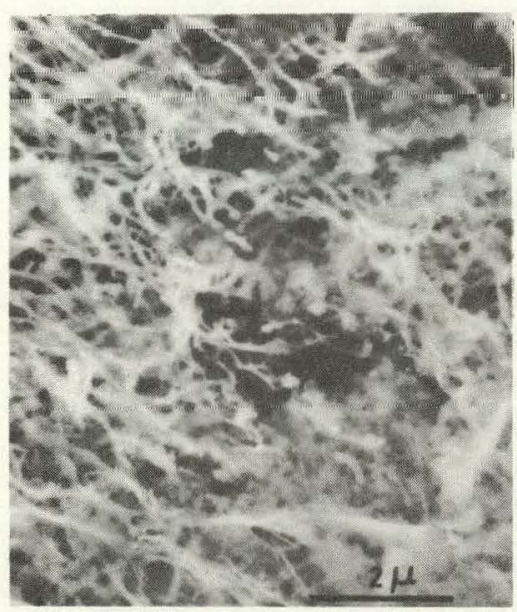

Fig. 3

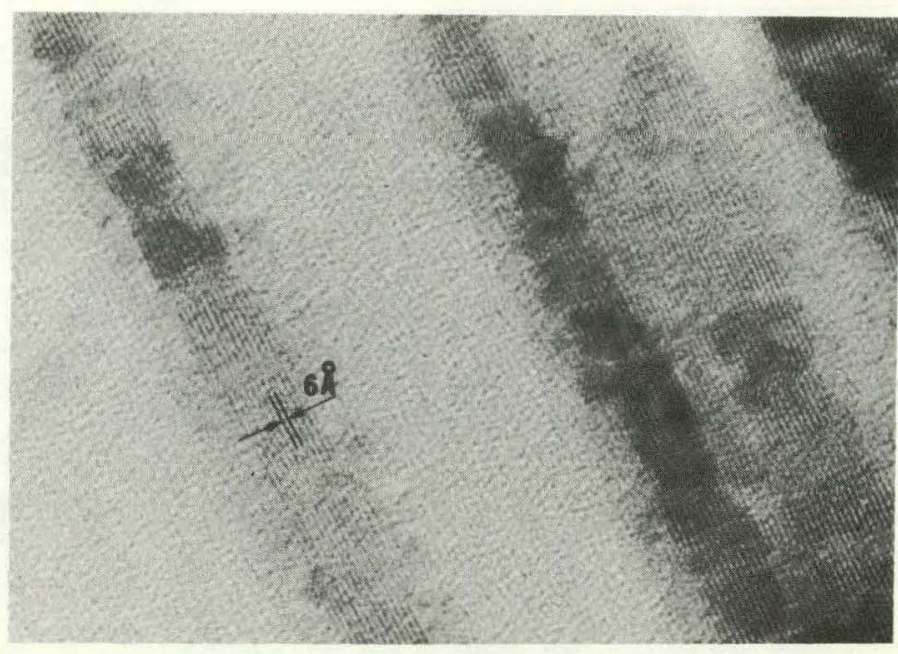

Fig. 2

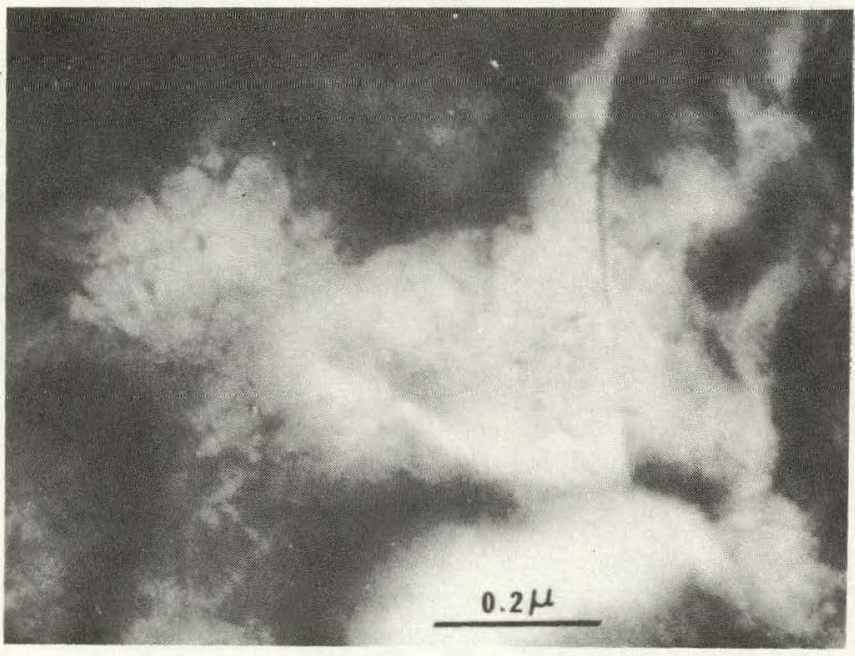

Fig. 4

XBB 705-2299

composite 
-4- UCRL-19628

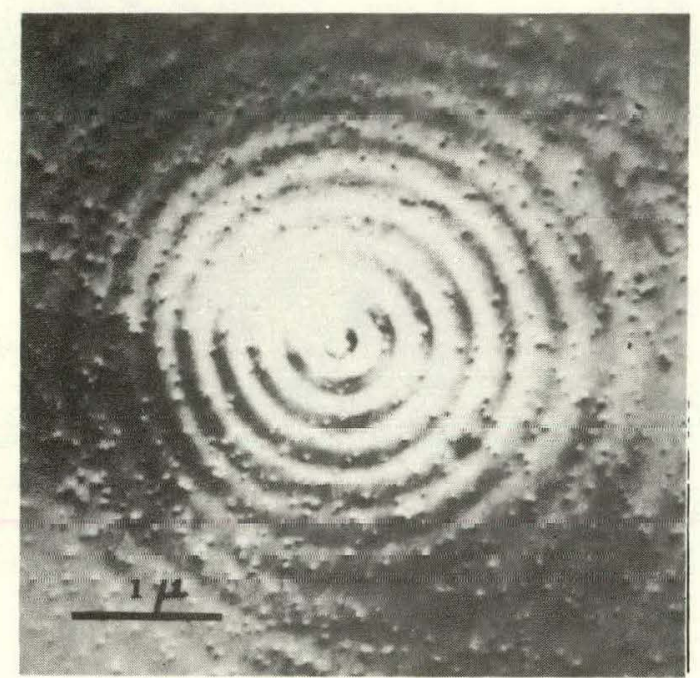

Fig. 5

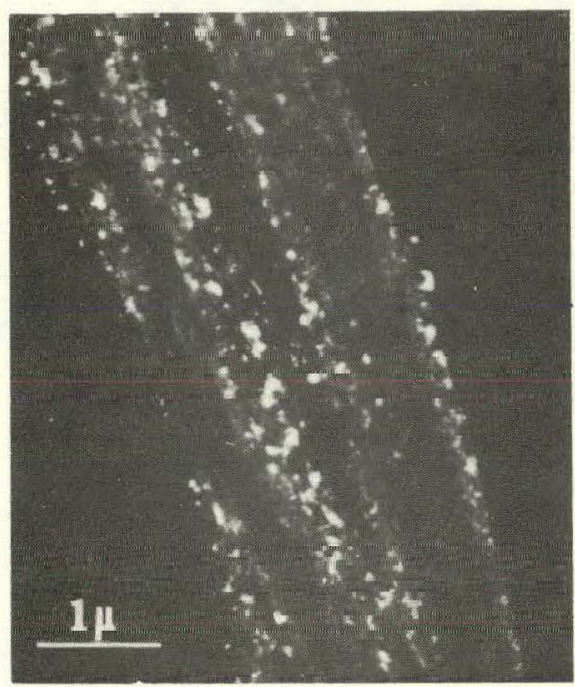

(a)

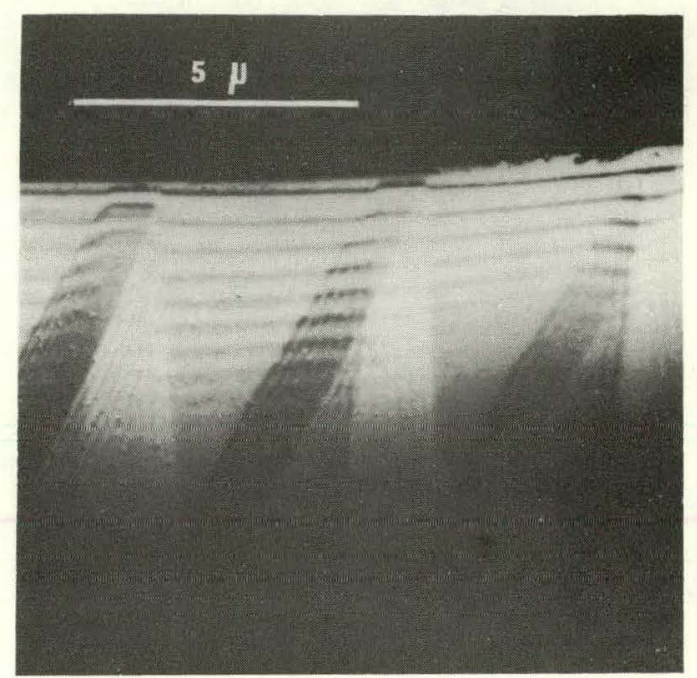

Fig. 6

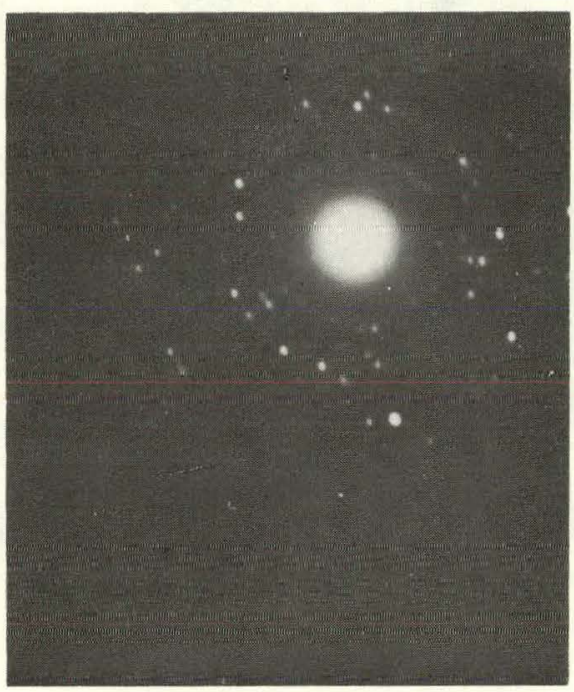

(b)

Fig. 7

XBB 705-2298

composite 


\section{LEGAL NOTICE}

This report was prepared as an account of Government sponsored work. Neither the United States, nor the Commission, nor any person acting on behalf of the Commission:

A. Makes any warranty or representation, expressed or implied, with respect to the accuracy, completeness, or usefulness of the information contained in this report, or that the use of any information, apparatus, method, or process disclosed in this report may not infringe privately owned rights; or

B. Assumes any liabilities with respect to the use of, or for damages resulting from the use of any information, apparatus, method, or process disclosed in this report.

As used in the above, "person acting on behalf of the Commission" includes any employee or contractor of the Commission, or employee of such contractor, to the extent that such employee or contractor of the Commission, or employee of such contractor prepares, disseminates, or provides access to, any information pursuant to his employment or contract with the Commission, or his employment with such contractor. 
